\title{
バランスチャート分析の ための計算方法の研究
}

\section{宇多 賢治郎}

\section{1. はじめに}

宇多（2019）で紹介した「バランスチャート」 は, スカイラインチャートでは示せない, 対外 取引による生産誘発効果の内訳を示せるように したものである。これにより, 都道府県や市町 村の地域内産業連関表で, 国外との「貿易」と 国内他地域との「交易」を分けて示すことが可 能になった。この「バランスチャート」は，ス
「バランスチャート」は, スカイラインチャートで示すこと ができない, 対外取引による生産誘発額の内訳を示せるように したものである. この生産誘発額の計算方法を, 大学の講義や セミナーなどで説明する場合は, 例として 3 部問程度の簡単な 表を用いることが多いであろう. これに対し, 実際の作業では 部門数が二桁以上の大きな表を用いることになる. また自治体 などの組織では, 異動により産業連関分析に緑がなかった人が 担当することがある.これらの状況を踏まえ, 産業連関分析の 経験がほぼない, 数学を苦手とする人でも, 多部門の産業連関 表で生産誘発額の計算を行い, 地域経済の分析に適切な部門数 に統合できるよう, Microsoft 社の Excel の操作と説明の方 法を研究した. では描くことができないため, プログラムを組 むなどの方法を採る必要があった.これに対し， 宇多（2019）ではそのプログラムの組み方の基 本的な説明を行い, 論文の公表に合わせて，ボ タンを押すだけでチャートを描けるプログラム を組みこんだExcel ファイル「X Ray」を公開 した ${ }^{1)}$.また, 2019 年 10 月 26 日に明治大学で 行われた「自治体・大学連携セミナー」で,「自 治体の産業連関表を活用するためのスカイライ 
ン分析の拡張 貿易・交易の内訳も示すグラフ の提案」と題し, バランスチャートの使い方を 説明した。

しかし，このセミナーの際，前提である生産 誘発額の計算の一切を省略したことで, 説明不 足になってしまったという印象を受けた。これ を踏まえ，バランスチャートを作成するために 必要な生産誘発額を, 経験のない自治体の職員 や大学の学部生が計算できるよう, 表計算ソフ 卜を使った作業方法とその説明方法を研究する ことにした。

授業やセミナーなどで説明する場合, 計算方 法は 3 部門程度の例が使われ，また実習では全 ての計算をExcelのシート一枚に収めたファイ ルが使われることが多いであろう。しかし，実 際の分析は二桁以上の部門数で行われることか ら，計算で用いる行列はパソコンのモニターか らはみ出るほど大きなものになるはずである. また, 地域内産業連関表を使って都道府県や市 町村で分析を行う場合, 細かい部門分類で計算 を行えば, その地域の主要産業が地域経済に与 える影響をより精密に捉えることができる.

そのため, できるだけ部門数の多い表で計算 してから,その地域の特徵を捉えられるように， 部門を統合することが望ましいことになる。し かし, 自治体では人事異動により, 産業連関分 析を知らないで担当になってしまった人には, 多部門で計算して統合することは，容易ではな いであろう。

これらのことを踏まえ, 今回は 2011 年の山 梨県産業連関表の統合小分類（190 部門）を例 に, データファイルの入手から, Microsoft 社 の Excel を使って生産誘発額を計算し, プログ ラムを使って部門を統合するまでの一連の作業 を行えるよう，説明方法の検討を行った。ま た, 産業連関分析に縁のなかった大学の学部生 に協力してもらい, 文書の説明だけで一連の作 業をこなせるか検証を行い, その観察結果を 踏まえて加筆を行った. 本稿では, 研究の概 要を本文で説明し，その成果である説明文を Appendix に示す.

\section{2. 計算の準備}

\section{2-1. 計算方法の概要}

生産誘発額の計算は, 産業連関分析では基本 であるため，公表した産業連関表の中に，生産 誘発額が掲載されていることも多い.このこと から，本論文誌でわざわざ生産誘発額の計算方 法を説明する必要はないと感じる人もいるであ ろう。

しかし，産業連関表によっては，自分で生産 誘発額を計算しなければならないことがある. 例えば，今回用いる 2011 年の山梨県産業連関 表の場合, 輸移出の生産誘発額は輸出と移出に 分かれておらず，また輸入，移入による負の生 産誘発効果は計算されていない。そのため，バ ランスチャートを作成するには，対外取引の項 目（移出，輸出，移入，輸入）に分けて，生産 誘発額を計算する必要がある。

これに加え, 自治体経済の分析を行う場合, その主要な産業の影響を捉えるには，できる限 り細かい部門分類で生産誘発額を計算してか ら，主要な産業部門を残すように統合すること が望ましい。例えば，山梨県で一般に知られて いる産業は，ブドウや桃などの「果物」やワイ ンやウイスキーなどの「酒類」である。しかし， これらは最も細かい統合小分類（以下，190 部 門表）では独立しているが, 統合大分類（以下， 37 部門表）では他の部門と統合されてしまっ ている。また，研究者のように専門分野に従事 できる立場と異なり，自治体などの組織には人 事異動がある。そのため, 数学の行列計算を理 解し，それを効率よく表計算ソフトで行えると いう条件が整っていない人が，産業連関分析の 担当者になることもある.

これに対し, 授業や講習などの場で計算方法 を説明する場合，基本的な理論を理解してもら うことを目的とするためか，3部門程度の単純 な産業連関表を例に用いることが多い.しかし， 実際の産業連関表はデー夕の多さから，数值を 
判読できる文字サイズで表示した場合，計算で 扱う行列が丸々パソコンのモニター内に収まる ことはまずない，そのため，画面からはみ出す 規模のデータを加工するための表計算ソフトの 操作方法を習得することが必要となる.

これらのことを踏まえ, 説明する文書の作成 にあたっては, 産業連関分析の知識と経験がな い学部生の協力を得た ${ }^{2)}$.また, 学生には, 手 順をまとめた文書を渡し, 筆者の目前で作業を してもらい，観察させてもらった。その結果を 踏まえ，加筆したものが本稿の Appendix であ る.

なお，本稿で用いる産業連関表は，本誌を発 行している環太平洋産業連関分析学会の Web サイト，上部メニューの「IO 表」にあるリン ク集からたどることができる，また，計算やグ ラフ描画を行わせるためのプログラムは，同 Web サイトの「分析ッール」でも公開してい るので，ぜひ活用いただきたい。

\section{http://www.gakkai.ne.jp/papaios/}

\section{2-2. チャートの描画と比較}

次に，多部門の産業連関表で生産誘発額の計 算を行い, 分析目的に合わせて統合した理由を 説明する。そのため求めた生産誘発額からスカ イラインチャートとバランスチャートを作成 し, チャート（グラフ）の此較を行う。今回 は，190 部門表から求めた生産誘発額を 37 部 門表に統合した值の他，37 部門表から求めた 值, また山梨県の産業の特徴を踏まえて 190 部 門の計算結果を 40 部門に統合した值の三種類 を用いる3)。なお, スカイラインチャートとバ ランスチャートの読み方, 描画方法, また描画 プログラムの「Ray3」と「X Ray」については, 宇多（2019）で説明しているため，省略する ${ }^{4)}$.

図 1 のスカイラインチャートと図 2 のバラン スチャートは，同じ 37 部門表を使って計算し た生産誘発額から作成した. 両図を比較すると, バランスチャートで貿易と交易を分けて示した
ことの効果が確認できる.

また，図 3 のバランスチャートは，190 部門 の計算結果を 37 部門に統合した值を使って作 成したものである。図 2 と図 3 を比較すると, 同じ 37 部門でもチャートの形状が異なってい ることが確認できる。このように，統合された 表で計算した結果と，細かい産業部門の表で計 算してから統合した結果には，違いが生じるた め，可能な限り細かい表で計算してから，統合 したほうが望ましいことが確認できる。

図 4 のバランスチャートは, 190 部門の計算 結果を 40 部門に統合した值を使って作成した ものである。この分類方法では，山梨県の産 業の特徵を示せるよう，190 部門表にある「4. 果実」，「26. 酒類」，「27．その他の飲料」を統 合せずに残した。これらの部門の山梨県内の生 産額に占める割合は $0.8 \%, 0.7 \%, 1.1 \%$ ，輸移 出額に占める割合はそれぞれ $0.9 \%, 0.7 \%, 1.3 \%$ である。これに対し，バランスチャートの横軸 である地域内，この場合は県内の最終需要によ る生産誘発効果はそれぞれ $0.1 \%, 0.3 \%, 0.2 \%$ と小さいため, 県内生産や対外取引で重要な産 業部門のグラフの横幅が小さく示されることに なる。このことから，バランスチャートやスカ イラインチャートは分析対象の経済構造を分か りやすく示す手段である一方, 地域内最終需要 による生産誘発効果が小さい場合は，重要な部 門が見えにくくなる，という性質があり，注意 が必要なことが分かる5).

\section{3. おわりに}

本稿では，汎用の表計算ソフトである Excel を使って，統合小分類（190 部門）の産業連関 表で生産誘発額を計算し，分析目的に合わせて 統合する方法を説明した。

産業連関分析の基本的な計算方法を，例えば 3 部問の簡単な表で説明された授業やセミナー を受講し，そのまま部門数が多い産業連関表を 使って効率よく計算する方法を習得する機会が なければ， 3 部問の方法をそのまま部門数の多 


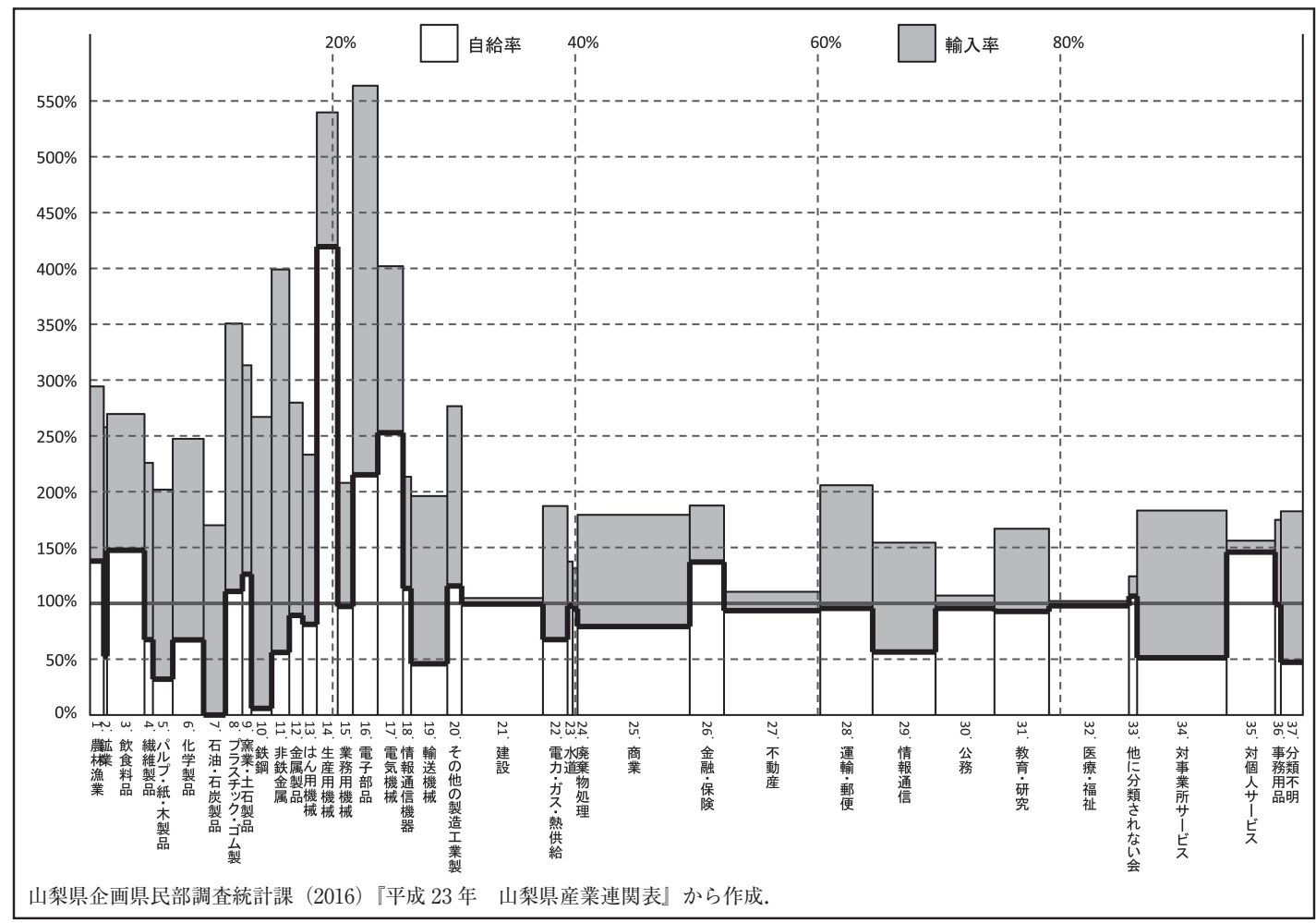

図 1 スカイラインチャート 37 部門で計算（高さは自動設定）

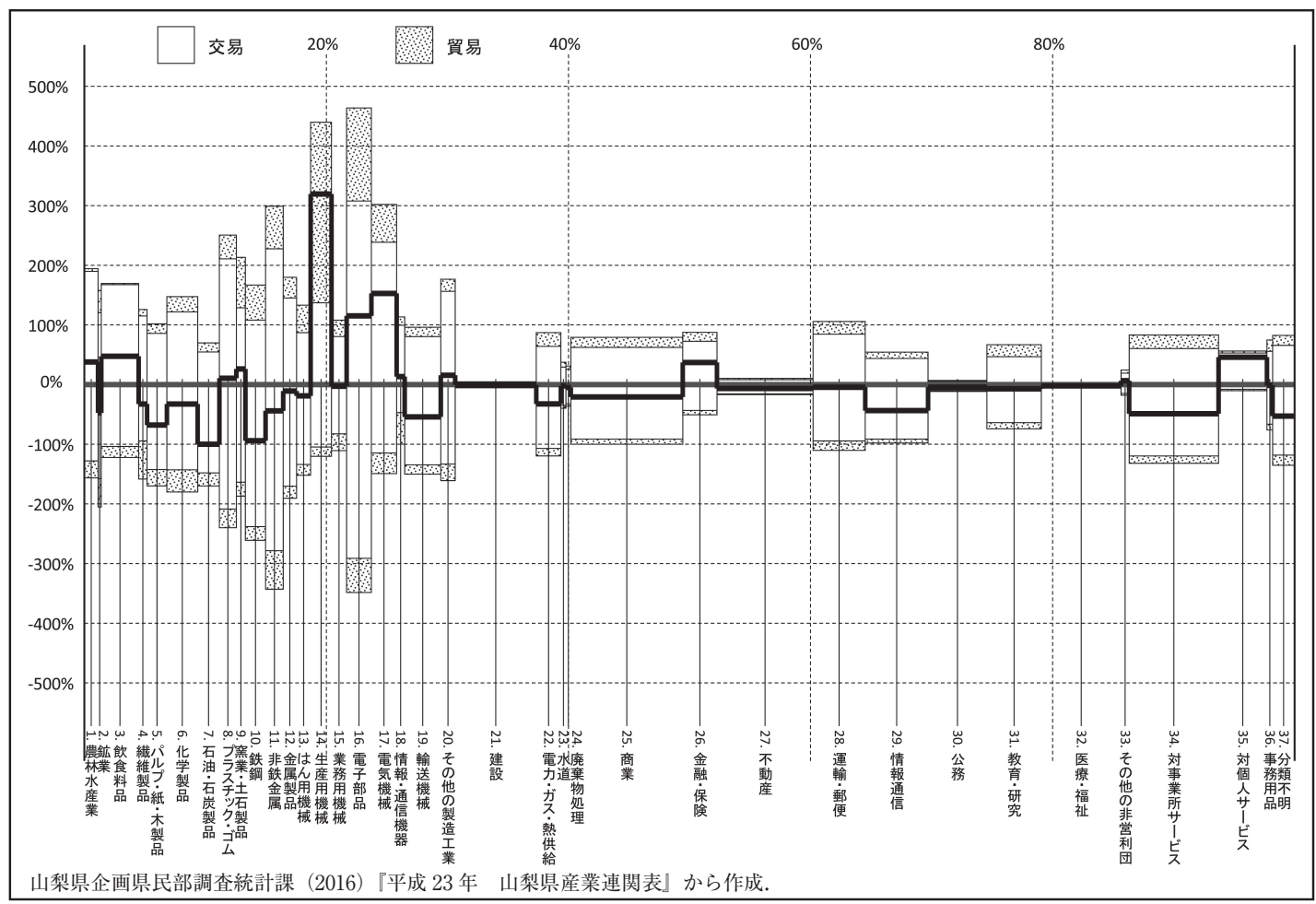

図 2 バランスチャート 37 部門で計算（高さを $560 \%$ に設定） 


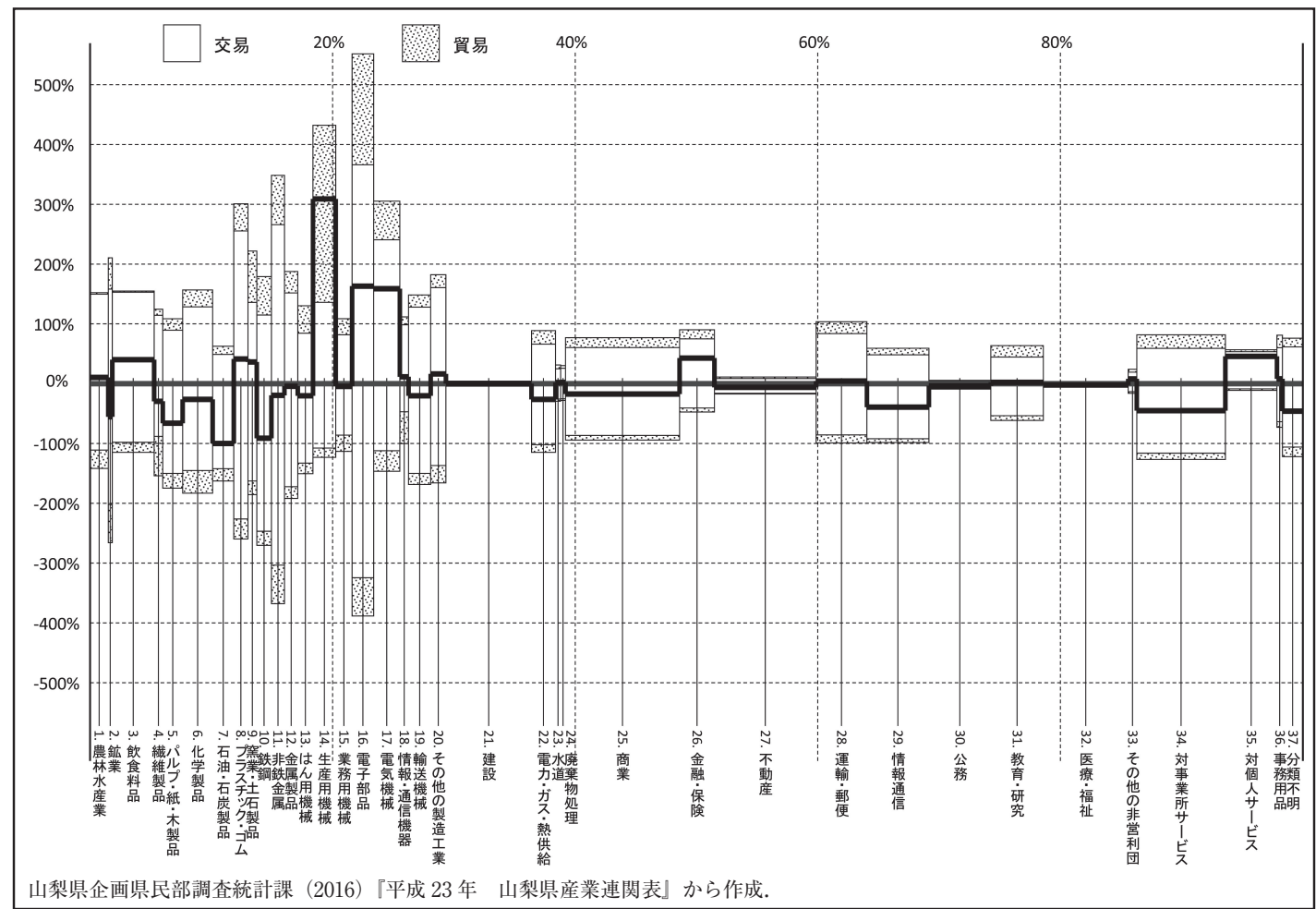

図 3 バランスチャート 190 部門で計算後, 37 部門に統合（高さを $560 \%$ に設定）

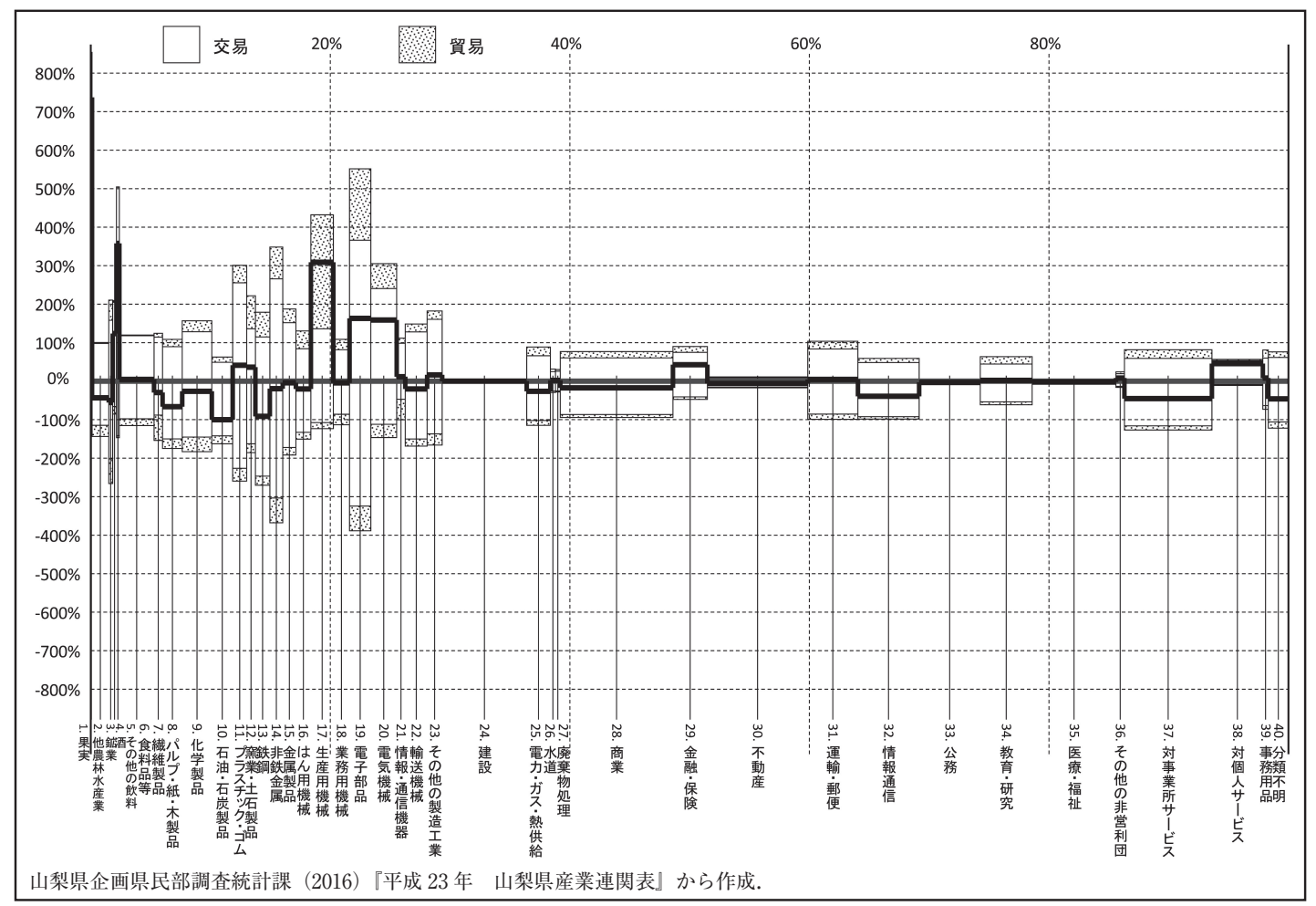

図 4 バランスチャート 190 部門で計算後, 40 部門に統合（高さは自動設定） 
い表に用いることになるであろう.しかし，こ の方法は効率が悪いため, たとえ計算を 190 部 門表でした方が望ましいとしても，少ない 37 部門で済ませたくなるであろう。

一方，近年の政策効果等の「見える化」によ り, 自治体の地域内産業連関表を使った分析が 活発になっている. そのため, 細かい部門分類 の表で計算を行い, 計算結果を地域の特徵を示 せるように部門を統合することが望ましい。こ のことを踏まえ, 本稿では部門数の多い産業連 関表を使った生産誘発額の計算と, 分析のため に計算結果を統合する方法を説明した。今回 は, 産業連関分析の経験がない人が担当するこ とになっても困らぬよう, 分析に必要な作業 方法を全く知らない人でも, とにかく本稿の Appendix の説明に従えば計算ができるよう, 説明方法を検討した.

なお，本稿で説明した方法を使って求めた 生産誘発額をそのまま用いるのではなく,「X Ray」を使って「バランスチャート」を作成す れば, 本稿で示したように, 地域の産業連関構 造に対し対外取引が与える影響を分かりやすく 示すことができる.「X Ray」や，それを解説 した宇多（2019）と併せて活用し，分析に役立 てていただきたい.

\section{〔注]}

1）バランスチャートの描画する Excel ファイル「X Ray」は, 以下の Web ページで公開している. また, スカイラインチャートを描画するファイルを更新し, $\lceil$ Ray3」として公開した.

http://www.ccn.yamanashi.ac.jp/ ${ }^{\sim} \mathrm{kuda} /$

2）今回は, 社会科の教員を志望する教育学部の学生 に協力してもらった.

3）統合には, 拙作の「統合.xlsm」を用いた. 今回用 いた 40 部門の分類は, 37 部門表に統合方法を基本に,

「4. 果実」, 「26. 酒類」, 「27. その他の飲料」を残
したものである.この分類は山梨県広聴広報課 (2019) と, 190 部門表を使って求めた生産誘発額を参考に 行った。 また, 他に, 他に電子部品, 加工機械, 生 産用機械関連の部門から, 特徵的な部門を統合せず に残すことも考えたが，統合される他の部門とそれ ほど変わらないため, 今回は分離しないことにした. なお, 40 部門に統合するための分類表は,「統合.xlsm」 にサンプルとして掲載している.

4)図 1 と図 4 は「Ray3」,「X Ray」に組み込んだ自 動機能を使って高さを設定したのに対し，図 2 と図 3 は比較のため, 高さを $560 \%$ に指定した.

5）バランスチャートに限らず，グラフや構成比，変 化率といった抽象化した值のように, 分かりやすく 示す有効な手段には，そのような欠点があることを， 用いる際, 説明を受ける際に注意する必要がある.

\section{参考文献一覧}

宇多賢治郎（2017）『教育の場で「説明する」ためのパ ソコン術』, 学文社.

宇多賢治郎 (2019)「スカイラインチャートなどのグラ フ描画プログラムを組む方法」, 『産業連関 一イノ ベーション \& IO テクニークー』, 第 27 巻第 1 号, 環 太平洋産業連関分析学会.

宇多賢治郎（2020）「プログラム教育の前に, 教員が理 解するための教材の一例」、教育実践総合センター 研究紀要』, 第 25 号, 山梨大学附属教育実践総合セ ンター。

宮沢健一 (2002)『日経文庫 857 産業連関分析入門〈新 版〉』, 日本経済新聞社.

山梨県企画県民部調査統計課（2016）『平成 23 年 山 梨県産業連関表』,

https://www.pref.yamanashi.jp/toukei_2/ HP/23renkan.html

山梨県広聴広報課（2019）『やまなし県のあらまし 2019』,

https://www.pref.yamanashi.jp/koucho/ aramashi/2019_aramashi.html

環太平洋産業連関分析学会 http://www.gakkai.ne.jp/ papaios/

産業連関表リンク集 http://www.gakkai.ne.jp/ papaios/iotable-g.html

分析ツール http://www.gakkai.ne.jp/papaios/tool. html 


\section{Appendix. 生産誘発額の計算（190 部門）と統合（37 部門）の方法}

\section{A-1. データの入手}

Appendix では, Microsoft 社の Excel を用い, 190 部門の大きな表でも効率よく生産誘発額を計 算し，主要な産業部門を残して分析に適した部門数に統合する方法を説明する ${ }^{6)}$.

本稿では例として, 山梨県の産業連関表を用いる. そのため, 山梨県の Web ページから, 2011 年の 190 部門表「23renkan-190bumon.xlsx」と 37 部門表「23renkan-37bumon.xlsx」を入手した ${ }^{7)}$. なお，入手したファイルを加工する際は，複製してオリジナルを残し，また区別のため名前を変更 しておくことを锄める.ここでは, 190 部門表のファイル名を「山梨表-2011-190.xlsx」とした 37 部門表は, 部門名のみ使用するため, 複製やファイル名の変更をする必要はない.

次に, 今回用いる 190 部門表の, 計算に用いるデータの座標をまとめたものが, 表 A1 である.

表 A1 山梨県産業連関表 (190 部門) の座標一覧

\begin{tabular}{|c|c|c|c|c|c|c|c|c|}
\hline & 内生部門 & $\begin{array}{l}\text { 県内 } \\
\text { 生产額 }\end{array}$ & $\begin{array}{c}\text { 県内 } \\
\text { 最終需要計 }\end{array}$ & 移出 & 輸出 & 移入 & 輸入 & $\begin{array}{c}\text { 県内 } \\
\text { 生産額 }\end{array}$ \\
\hline $\begin{array}{l}\text { 山梨県 } \\
190 \text { 部門 }\end{array}$ & $\begin{array}{l}\text { セル D4 } \\
\sim \text { GK193 }\end{array}$ & $\begin{array}{l}\text { セル D205 } \\
\quad \sim \text { GK205 }\end{array}$ & $\begin{array}{l}\text { セル GV4 } \\
\sim \text { GV193 }\end{array}$ & $\begin{array}{l}\text { セル GZ4 } \\
\sim \text { GZ193 }\end{array}$ & $\begin{array}{l}\text { セル GX4 } \\
\sim \text { GY193 }\end{array}$ & $\begin{array}{l}\text { セル HH4 } \\
\sim \text { HH193 }\end{array}$ & $\begin{array}{l}\text { セル HD4 } \\
\sim \text { HG193 }\end{array}$ & $\begin{array}{l}\text { セル HK4 } \\
\sim \text { HK193 }\end{array}$ \\
\hline
\end{tabular}

輸出と輸入の欄で複数の列を示しているのは, 190 部門表では輸出は「輸出」と「輸出 (直接購入)」 に, 輸入は「(控除) 輸入」,「(控除) 輸入 (直接購入) $」, 「($ 控除 $)$ 関税」,「(控除) 輸入品商品税」 に分かれおり，計算の際はSUM 関数で足すなどして，統合する必要があることによる.

\section{A-2．作業を効率化する原則と操作方法}

部門数の多い産業連関表を使って計算など, 画面からはみ出るほどの大量のデー夕を扱うコツは, 範囲選択を効率よく行うための操作方法を身に付けることと, それらの方法を活用できる状況を整 えることである. 以下は，そのための原則をまとめたものである ${ }^{9)}$.

・範囲選択の操作では, 極カマウスを使わないようにする（操作 1 ～5）

・ショートカット操作を用いる（操作 6)

・行列の計算は, 1 シート 1 つに留める

・シート名は簡潔にする（今回は, 最長でも二文字に留めた）

・産業連関表のシートを複製したものを加エして, 計算用のシートとして再利用する

・複製したシートのデータは消さずに残し，範囲選択の操作の際に利用する

・表の羁線（枠線）を消し，值は灰色に塗り，隣と同じ計算をする場合は同じ色に塗る セルに塗る色を揃えるのは，作業内容を視覚的に把握できるようにするためである. 次に, 頻繁に用いる操作方法を説明する. 
操作 1.「ウインドウの枠固定」を使つた, 移動の効率化

今回，例として用いる山梨県の 190 部門表は，部門名がC 列と 3 行に，值はセル D4より も右下に配置されている。つまり，上記の原則に基づいて作業を行う場合，各シートのセル D4 に移動しやすいようにしておくと，作業がしやすくなる．そのため， A 〜 C 列, 1 ○ 3 行 が常に表示されるよう，「ウィンドウ枠の固定」という設定をしておくのである.（図 $\mathrm{A} 1$ )

図A1 ウィンドウ枠の固定

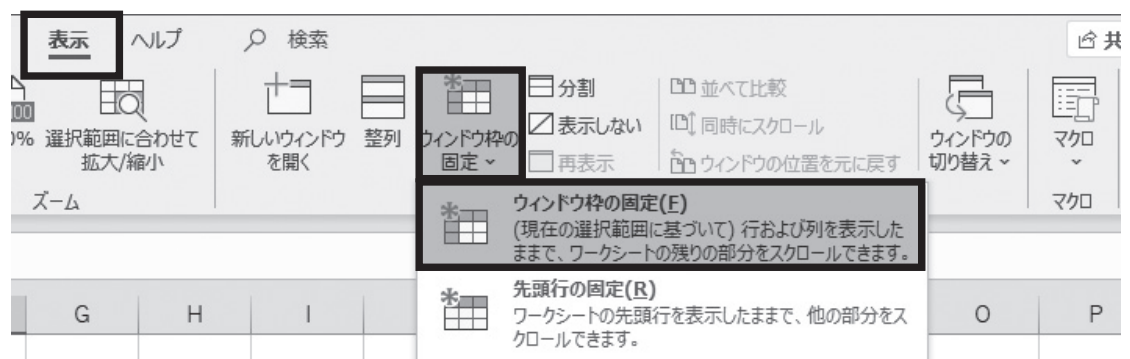

手順 1. 固定するウィンドウ枠右下に位置するセルを選択する

手順 2.メニュー「表示」の「ウィンドウ」欄にある，「ウィンドウ枠の固定」を選択する

手順 3. 現れたメニューの上部にある，「ウィンドウ枠の固定」を選択する

これにより，行 C と D の間と列 3 と 4 の間に灰色の線が引かれ， A 〜 C 列, $1 \sim 3$ 行が, 常に 表示されるようになる.

なお, 今回用いる 190 部門表は設定がされているため, この操作を行う必要はない.

\section{操作 2． 行列の左上への移動（例：セル D4への移動）}

「ウィンドウ枠の固定」がされている場合，画面に表示されていないセル D4 に戻るには，次の 操作を行う.

手順 1. セル C3 を選択する

カーソル (マウスの矢印) を重ね, マウスの左ボタンを押す操作を,「選択する」と表記する.

手順 2. キーボードの「 $\rightarrow 」($ 右）キー,「」」（下）キーを一度ずつ押す

「操作 1」により，七ル C3 が常に表示されていれば，簡単にセル D4 に移動できる.

操作 3. シート内の移動は，スクロールバーを使う

今回の計算では，同じシートの画面に同時に表示されない離れたセル，行，列を範囲選択すること が必要になる。本稿では説明の簡略化のため, 既に文字が入力されているシートを再利用することで, Excel の操作画面の右側と下側にあるスクロールバーを使って移動する方法のみ用いる。（図 A2）

図 A2 スクロールバーを使った表示部分の移動

\begin{tabular}{c|r|r|r|r|r|}
\hline 0.408 & 2.914 & 16.112 & 0.087 & 31.147 & 13.8 \\
\hline-22.276 & -4.140 & -150.514 & -1.671 & -38.334 & 91.8 \\
\hline$j 81.422$ & 3961.354 & 20997.980 & 134.323 & 2949.478 & 7982.6 \\
\hline 1515 & 10.202 & 57101 & 0202 & 70241 & 11 \\
\hline & $\vdots$ & & & \\
\hline
\end{tabular}


手順 1.スクロールバーにカーソルを重ね，マウスの左ボタンをおさえる

手順 2. カーソルを右に, 動かしたい分だけ移動する（選択したセルはそのまま, 表示が変わる)

スクロールバーを使って移動できる範囲は, 既に文字の入力がされたことのあるセルまでである. そのため，データが入力されていない場合に，この移動方法を用いることはできない.

\section{操作 4.「Shift」キーを使つた範囲選択}

本作業では，複数の行や列をまるごと範囲選択することがある。そこで，操作 3 の「スクロール バー」を使った移動と，以下の「Shift」キーを使った範囲選択を組み合わせて用いる.

例えば，GL列から画面外にある HK 列まで，範囲選択する方法を説明する.

図 A3 列ごと選択（「列番号」の「GL」を選択）

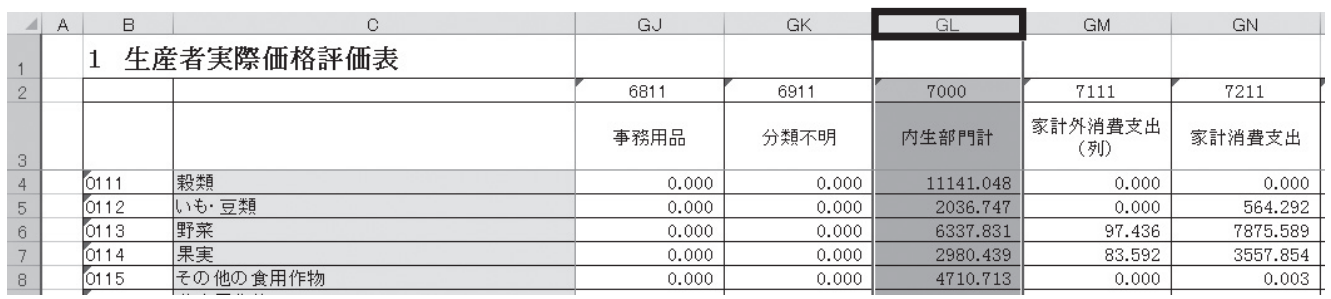

手順 1.「列番号」の「GL」の上で，マウスの左ボタンを押す（図 A3）

手順 2. 操作 3 で, 「列番号」の「HK」が表示されるまで移動する

手順 3.「Shift」キーをおさえながら，「列番号」の「HK」の上で，マウスの左ボタンを押す （GL 列から HK 列まで，列ごと選択される.）

\section{操作 5. データをまとめて範囲選択}

生産誘発額の計算では，画面からはみ出すサイズの行列（190 行× 190 列）を，何度も範囲選択

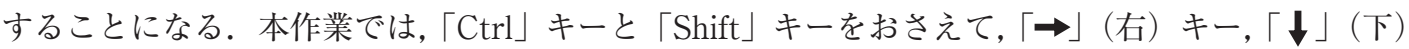
キーを押して範囲選択する方法を用いる，例えば「か」キーを押すと，次のように範囲選択がされる. ・右真横のセルに文字が入力されている場合は, 文字が入力されていないセルの手前（一つ左）まで ・右真横のセルに文字が入力されていない場合は, 次に文字が入力されているセルまで そのため, 白紙のシートでこの操作を行うとシートの果てまで, 例えば右端 (XFD 列, 横 16,384 番) に移動してしまう。この場合,「Ctrl」キーと「Shift」キーをおさえて「ヶ」(左) キーを押せば戻れる。

操作 6. ショートカット操作を用いる

コピーや貼り付けは，マウスの右ボタンを使わず，ショートカット操作を用いるとよい.

ショートカット操作の説明では, 明朝体が「おさえる」キー, ゴシック体が「押す」キーを示す。 
図 A4「形式を選択して貼り付け」の設定画面

\begin{tabular}{|c|c|}
\hline 形式を選択して貼り付け & $\times$ \\
\hline \multicolumn{2}{|l|}{ 貼付け } \\
\hline$\bigcirc す \wedge \tau(\underline{A})$ & ○コ゚゙-元のテーマを使用しすの゙て貼り付け(ㅂ) \\
\hline ○数式(E) & ○䍘線を除〈す介テて $(\underline{x})$ \\
\hline O誼(V) & ○列幅(W) \\
\hline $\mathrm{O}$ 書式(I) & ○数式と数值の書式( $(\underline{R})$ \\
\hline ○コxント(드) & ○值と数值の書式(约) \\
\hline ○入力規則(N) & すハての䊅合されている条件付き書式(G) \\
\hline \multicolumn{2}{|l|}{ 演算 } \\
\hline ○しない(ㅇ) & ○粪算(M) \\
\hline ○加算(吕) & ○ 除算(I) \\
\hline \multicolumn{2}{|l|}{ ○減算(古) } \\
\hline 口空白セルを無視する(B) & $\square$ 行/列の入れ替云(E巨) \\
\hline \begin{tabular}{|l|} 
リク貼り付け(し) \\
\end{tabular} & キャンセル \\
\hline
\end{tabular}

例えば，「Ctrl $+\mathrm{C} 」 な ら ，$ 先に「Ctrl」キーをおさえたまま，「C」キーを押し，終わったらおさ えていた「Ctrl」キーから指を離す，という手順で作業を行う ${ }^{10)}$. 本稿で用いるのは，「Ctrl +C」 (コピー), 「Ctrl $+\mathrm{V} 」($ 貼り付け), 「Ctrl $+\mathrm{Alt}+\mathrm{V}\rfloor$ (「形式を選択して貼り付け」の設定画面を表示) の三種である.

なお，「形式を選択して貼り付け」の設定画面（図 A4）の，各項目の右にある文字を押すことで， 設定の操作を簡単に行うことができる．例えば「V」キー,「Enter」キーの順に押すと,形式を「值」 にし「○K」を押したことになる。

\section{操作 7.「Esc」キーの活用}

「Esc」キーを押すと，選択しているセルで行っている作業をなかったことにしてくれる.

例えば，関数を使って逆行列や行列の掛け算を行なった場合，計算結果の一部だけを変更するこ とはできなくなる，そのため，誤操作によって一部を変更する操作をしたことになれば，「配列の 一部は変更できません.」と表示され, 作業が続けられなくなってしまうこともある。こういう時に， 「Esc」キーを押すのである。

\section{操作 8. パソコンの動作が遅くなつた場合の対処方法}

Excel は，一つ操作をするごとに計算を全てやり直すように設定されている．今回は，190× 190 の行列を用いるため, 大量の計算が繰り返されることになる. しかし, 中間投入係数行列の計 算からレオンチェフ逆行列の計算までは，一度してしまえばよいものである.

そこで,これらの計算は繰り返さないよう,式を計算結果,つまり「值」に変換してしまうとよい.

手順 1. 操作 5 を使い，計算がされている箇所を範囲選択する $(\mathrm{Ctrl}+\mathrm{Shift}+\rightarrow, \mathrm{Ctrl}+\mathrm{Shift}+\downarrow)$

手順 2.コピーする $(\mathrm{Ctrl}+\mathrm{C})$

手順 3. 操作 6 を使い，コピー $(\mathrm{Ctrl}+\mathrm{C})$ したものを「值」で貼り付ける $(\mathrm{Ctrl}+\mathrm{Alt}+\mathrm{V}, \mathrm{V}$, Enter $)$

つまり，計算式が書かれている所に計算結果（值）を上書きして，計算を繰り返し行わないよう にしてしまうのである. 


\section{A-3. 計算用シートの準備}

前述の「行列の計算は，1 シートに1つのみ」の原則に従い，中間投入行列 $\mathrm{A}$ の計算，単位行 列 I の作成, I-A の計算, レオンチェフ逆行列 B の計算までは, それぞれ別のシートで行う ${ }^{11)}$. また, それぞれの行列の計算は, 各シートのセル D4 から GK193 で位置を揃えて行う。そのため, 各シー トの設定を初めにしてしまう，今回は，産業連関表の「基本表」のシートを複製し，加工する方法 を用いる。

\section{作業 1.シート「基本表」以外のシートを削除する}

不要なシートの名前（シート見出し）の上でマウスの右ボタンを押し，「D」キーを押す。

なお，「操作 $4 」$ の応用で，シート「投入係数表」の「シート見出し」を選択し，「Shift」キーを おさえながらシート「移輸入係数_総合移輸入係数等」の「シート見出し」を選択すると, シート をまとめて選択できる。これにより，たくさんのシートを一度に削除することができる。

なお, 削除すると, 警告文のように消したシートは消失し, 戻すことができないので注意すること.

\section{作業 2. シート「基本表」の名前を，「IO」に変更する}

シート「基本表」の名前（シート見出し）上で, マウスの左ボタンをダブルクリック（二回素早 く押す）と，シート前の変更ができるようになる。（ならない場合は，押す速さを変えてみること.）

\section{作業 3. シート「IO」の複製と名前の変更}

図 A5 シートの複製

$62+10$

手順 1.「Ctrl」キーをおさえ，シート「IO」の「シート見出し」の上でマウスの左ボタンを おさえる

手順 2.マウスの左ボタンをおさえたまま複製したい位置にカーソル（マウスの矢印）を移動する 複製の場合，カーソルの白紙に「十」が追加される。（図 A5)

手順 3. シート「IO (2)」が作成されるので，作業 2 の方法で名前を「A」に変更する

\section{作業 4. シート「A」の GL 列から HK 列を削除する}

手順 1. 操作 4 を使って, GL 列から HK 列を範囲選択する

手順 2. 範囲選択した箇所の上で，マウスの右ボタンを押す

手順 3. マウスの右ボタンを押し，一覧が現れたら「D」キーを押す

マウスの右ボタンを押し, 現れた一覧から「削除」を選択する,でもよい。 
作業 5. シート「A」の 194 行から 205 行を削除する

手順 1. 操作 4 を使って, 194 行から 205 行を範囲選択する

手順 2. 範囲選択した箇所の上で，マウスの右ボタンを押す

手順 3.マウスの右ボタンを押し，一覧が現れたら「D」キーを押す

マウスの右ボタンを押し, 現れた一覧から「削除」を選択する,でもよい.

作業6. シート「A」の加工

今回は，産業連関表が配置されているシートを複製した，シート「A」を活用することで，作業 の効率化を図る，そのため，シート「A」を作業がしやすいように加工する.

そのため，買線を取り去り，190行×190列の行列に同じ色を塗る.

手順 1. セル D1 に，適当な数值を入力する（今回は，「-1」と入力）

手順 2. セル D1 で，小数点を表示させる（例えば，第三位まで.）

手順 3. セル D4 の買線（枠線）を消し,塗りつぶす（「買線なし」を選択し,例えば水色に塗る.）

手順 4. セル D4 を選択し,「Ctrl +C」を押す（コピー）

（範囲選択した箇所が, コピーする対象であることを示すよう, 周囲に点線が回るようになる.）

手順 5. セル D4 の周囲で点線が回るようになったら，「Ctrl」キーと「Shift」キーをおさえな

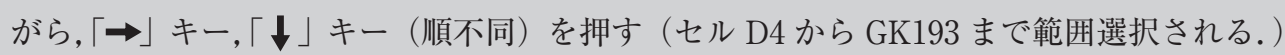

手順 6. $「 \mathrm{Ctrl}+\mathrm{V} 」$ を押す（貼り付け）

(セル D1の内容が，セル D4 から GK193 に貼り付けられる.)

これで，セル D4 から GK193 に羁線がなく，セルが同じ色に塗られた「-1.000」の行列ができる.

また不可欠ではないが， 3 行と C 列にある，部門名の郝線を消し，色は「塗り潰しなし」を設定 しておくと，以降の作業で表が見やすくなる.

作業 7. シート「A」を複製し，それぞれ名前を「IJ,「IA」,「B」,「F」に変更する

手順 1. 作業 3 の方法で, $\mathrm{A}$ を複製する作業を 4 回行う

(シート「A(2)」,「A(3)」,「A(4)」,「A(5)」が作成される.)

手順 2. 作業 2 の方法で，それぞれ名前を「I」，「IA」，「B」,「F」に変更する

シート名を「I-A」にすると, 計算式のマイナスと混同してしまうため, 今回は「IA」と表記した.

\section{A-4. 計算の準備と中間投入係数行列の計算}

地域産業連関表の場合，部門分類が細かくなると，中間投入係数の計算で分母になる生産額が 0 の部門が増える。しかし, Excelでは割り算の分母が 0 の場合, 計算結果は「\#DIV $/ 0 」(0$ 除算の エラー）と表示され, 中間投入係数行列の計算ができなくなる ${ }^{12}$.

この問題を回避するように, IF 関数を使い, 条件をつけて計算を行う必要がある.

作業 8. シート「A」に県内生産額を表示する

まず，中間投入係数の分母である生産額が「0」であるかを確認しやすくするため，シート「A」 の一行目に生産額を表示するように設定する。 
手順 1. シート「A」のセル D1 に,「=IO!D205」と入力し, 「Enter」キーを押す

以下，入力後に「Enter」キーを押す説明は省略し，「入力する」のみ表記する.

（シート「IO」の 205 行にある生産額の值が, シート「A」の 1 行目に表示される.）

手順 2. セル D1 で，小数点を表示させる（例えば，第三位まで表示する.）

手順 3. セル D1 を塗りつぶす（例えば，薄緑色に塗る.）

手順 4. セル D1 を選択し，「Ctrl +C」を押す（コピー）

手順 5. 七ル GK1 が表示されるように，スクロールバーを右に動かす（操作 3 を参照）

手順 6. セル GK1 の上にカーソルを重ね，Shift キーをおさえながら，マウスの左ボタンを押す

手順 7.「Ctrl $+\mathrm{V} 」$ を押す（貼り付け）

\section{作業 9. 中間投入係数行列「A」の計算}

地域内産業連関表の部門分類は，全国表の部門分類を参考に作成されるため，部門分類を細かく なると，生産額が 0 の部門が生じやすくなる。この場合，中間投入係数の計算を行うと，生産額が 分母になるので $0 て ゙$ 割り算してしまうことになる，そこで, 式に条件付けを加える必要がある。（図 A6)

図 $\mathrm{A} 6$ 中間投入係数行列の計算

\begin{tabular}{|c|c|c|c|c|c|c|c|}
\hline 4 & A & B & C & D & $E$ & $\mathrm{~F}$ & G \\
\hline 1 & & 1 生 & 者実際価格評価表 & 6,672 & 1,232 & 9,166 & 50,805 \\
\hline 2 & & & & 0111 & 0112 & 0113 & 0114 \\
\hline 3 & & & & 款類 & いも・豆類 & 野菜 & 果実 \\
\hline 4 & & 0111 & 穀類 & \multirow{2}{*}{\multicolumn{2}{|c|}{$=\mathrm{IF}(\mathrm{D} \$ 1=0,0, \mathrm{IO} ! \mathrm{D} 4 / \mathrm{D} \$ 1)$}} & -1.000 & -1.000 \\
\hline 5 & & 0112 & (、も·豆類 & & & -1.000 & -1.000 \\
\hline 6 & & 0113 & 野菜 & -1.000 & -1.000 & -1.000 & -1.000 \\
\hline
\end{tabular}

手順 1. シート「A」のセル $\mathrm{D} 4$ に, $「=\mathrm{IF}(\mathrm{D} \$ 1=0,0, \mathrm{IO} ! \mathrm{D} 4 / \mathrm{D} \$ 1) 」$ と力する

手順 2. セル D4 を選択し，「Ctrl +C」を押す（コピー）

手順 3. セル D4 の周囲で点線が回るようになったら，「Ctrl」キーと「Shift」キーをおさえな がら,「 $\rightarrow 」$ キー,「」」キー（順不同）を押す（セル D4 から GK193 まで範囲選択される.）

手順 4. $「 \mathrm{Ctrl}+\mathrm{V} 」$ を押す（貼り付け）

これにより，計算式の分母，つまり生産額が 0 の場合は「0」と記入され，それ以外なら中間投 入係数の計算が行われることになる.

\section{A-5. レオンチェフ逆行列の計算}

以下の説明は，作業 6 により，各シートのセル D4 から GK193 が同じ色に塗られ，「-1.000」と 表示されていることを前提とする.

\section{作業 10. 単位行列の計算の事前準備（シート「I」）}

単位行列の入力は，空白のセルを計算色に組み込むと「0」として扱われることと，対角（左上 から右下の対角）が「1」であるという性質を利用する ${ }^{13)}$.

まず，単位行列の計算を妨げる，表の上（3 行）と左（C 列）にある，部門名を消す必要がある. 
手順 1. シート「I」のセル C4 を選択し,「Ctrl」キーと「Shift」キーをおさえながら,「ね」キー を押す（セル C4 から C193 まで選択される.）

手順 2.「Delete」キーを押す

手順 3. セル D3 を選択し,「Ctrl」キーと「Shift」キーをおさえながら,「ー」キーを押す（セ ル D3 から GK3 まで範囲選択される.）

手順 4.「Delete」キーを押す

「Delete」キーを押した場合は, 範囲選択した箇所の文字が全て消去される．この場合は, 作業 4, 作業 5 で行った行，列の「削除」の操作のように，七ルそのものは削除しない ${ }^{14)}$. (図 A7)

作業 11 . 単位行列の計算（シート「リ）

次に，シート「I」で，中間投入係数行列の計算を単位行列の計算に差し替える.

シート「I」は，作業 6 で作成したシートのコピーであるため，「-1.000」が並んでいる．（図 A7）

\section{図 A7 単位行列の作成}

\begin{tabular}{|c|c|c|c|c|c|c|}
\hline & B & c & D & $E$ & $F$ & G \\
\hline 1 & 1 生 & 生産者実際価格評価表 & & & & \\
\hline 2 & & & 0111 & 0112 & 0113 & 0114 \\
\hline 3 & & & & & & \\
\hline 4 & 0111 & & $=\mathrm{C} 3$ & -1.000 & -1.000 & -1.000 \\
\hline 5 & 0112 & & & -1.000 & -1.000 & -1.000 \\
\hline 6 & 0113 & & -1.000 & -1.000 & -1.000 & -1.000 \\
\hline 7 & 0114 & & -1.000 & -1.000 & -1.000 & -1.000 \\
\hline 8 & 0115 & & -1.000 & -1.000 & -1.000 & -1.000 \\
\hline
\end{tabular}

手順 1. シート「I」のセル C3 を選択し，「1」と入力する

手順 2. セル $\mathrm{D} 4$ に, $「=\mathrm{C} 3 」$ と力する

手順 3. セル D4 を選択し，「Ctrl +C」を押す（コピー）

手順 4. セル D4 の周囲で点線が回るようになったら，「Ctrl」キーと「Shift」キーをおさえな がら,「 $\rightarrow\rfloor$ キー,「】」キー（順不同）を押す（セル D4 から GK193 まで範囲選択される.）

手順 5. $「 \mathrm{Ctrl}+\mathrm{V} 」$ を押す（貼り付け）

作業 12. I-A の計算（シート「IA」, 画像省略）

手順 1. シート「IA」のセル D4 に，「=I!D4-A!D4」と入力する

手順 2. セル D4 を選択し, 「Ctrl +C」を押す（コピー）

手順 3. セル D4 の周囲で点線が回るようになったら，「Ctrl」キーと「Shift」キーをおさえな がら,「 $\rightarrow 」$ キー「】」キー（順不同）を押す（セル D4 から GK193 まで範囲選択される.）

手順 4. $「 \mathrm{Ctrl}+\mathrm{V} 」$ を押す（貼り付け）

作業 13. レオンチェフ逆行列 B の計算（シート「B」, 画像省略）

作業の途中で, うまくいかなくなったら「Esc」キーを押し, 手順 1 からやり直すこと.（操作 7 ). 
手順 1. シート「B」のセル D4 を選択する

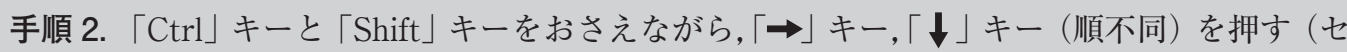
ル D4 から GK193 が選択される.)

手順 3. そのまま「=MINVERSE(IA!D4:GK193)」と入力する

「そのまま」, つまりセル D4 を選択するなどの操作を何もせずに, 文字の入力をすること.

セル D4に記入される.「=MINVERSE(」まで書いて, シート「IA」のセル D4を選択し, 「Ctrl」

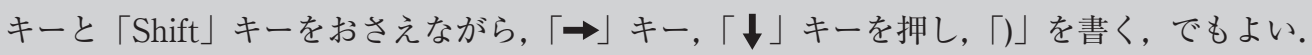
手順 4.メニュー上部にある「数式バー」を選択する（図 A8 の黑枠内）

この操作は, Excel のバージョンによって必要ないことがある.

手順 5.「Ctrl」キーと「Shift」キーをおさえながら，「Enter」キーを押す

図 A8 作業 13 の手順 4 で, 選択する「数式バ一」(黒枠線内)

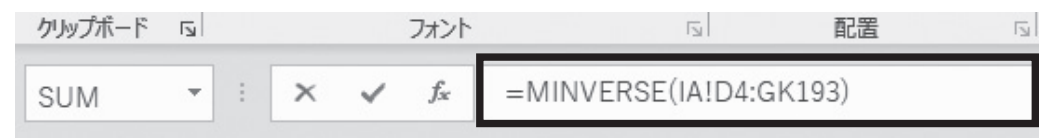

\section{A-6. 最終需要の抽出}

まずシート「F」に最終需要の值を, シート「IO」から「引用」する.

作業 14. 最終需要額の「引用」の準備（シート「F」）

手順 1. シート「F」の J 列上部の「列番号」の「J」にカーソルを重ね, マウスの左ボタンを押す

手順 2. GK 列が表示されるように，スクロールバーを右に動かす（操作 3 を参照）

手順 3. GK 列上部の「列番号」の「GK」で，「Shift」キーをおさえながら，マウスの左ボ夕 ンを押す

手順 4. マウスの右ボタンを押し，「D」キーを押す

作業 15. 最終需要部門名の準備（シート「F」）

正確に值が引用しているか確認しやすいように，部門名を比較できるようにする.

手順 1. シート「F」のセル D2 に「県内最終需要計」, セル E2 に「移出」, セル F2 に「輸出」, セル $\mathrm{G} 2$ に「移入」, セル H2 に「輸入」, セル $\mathrm{I} 2$ に「県内生産額」と記入する

手順 2. セル D4 から I2 まで, 2 色で交互に塗りつぶす

例えば，セル D4，F4，H4 を水色，七ル E4，G4，I4 を薄緑色に塗る.

手順 3. D 列上部の「列番号」の「D」にカーソルを重ね, マウスの左ボタンを押す

手順 4. I 列上部の「列番号」の「I」で Shift キーをおさえながら，マウスの左ボタンを押す

手順 5.「Ctrl $+\mathrm{C} 」$ を押す（コピー）

手順 6. セル K1 を選択し, 「Ctrl + V」を押す（貼り付け）

(D 列から I列の内容が，K列から P 列に貼られる.）

手順 7. セル K2 から P2（部門名）を, セル K3 から P3 に貼り付け，七ル K2 から P2 まで, またセル P3 に書かれた文字を消す（これまで説明した操作方法を, 組み合わせる.） 
作業 16. 最終需要額の「引用」（シート「F」）

最終需要額は, 産業連関表から「コピーして貼り付ける」のではなく, 式を使って別のセルから 「引用する」する方法で用意する，なお，統合する必要がある箇所では，合計する．

図 A9 最終需要の引用と統合

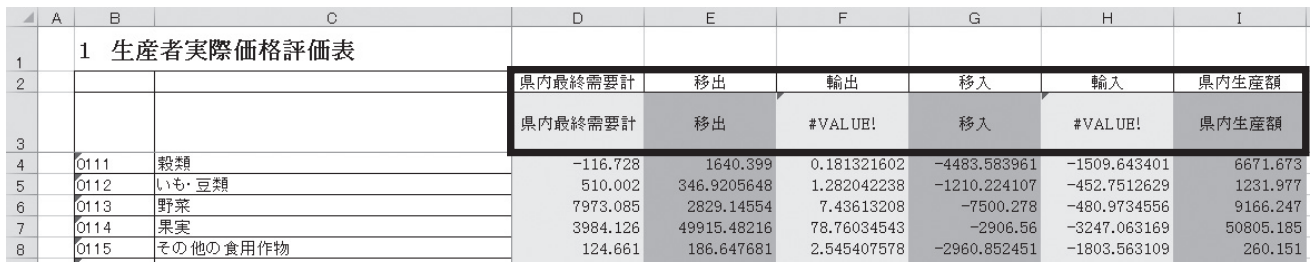

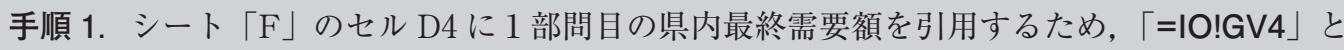
入力する

手順 2. セル E4 に 1 部問目の移出額を引用するため, 「=IO!GZ4」と入力する

手順 3. セル F4 では輸出額を合計するため，「=1O!GX4+IO!GY4」と入力する

(「輸出」=「輸出」と「輸出 (直接購入) $\rfloor)$

手順 4. セル G4 に移入額を引用するため, 「=IO!HH4」と入力する

手順 5. セル H4 では輸入額を合計するため, 「=IO!HD4+IO!HE4+IO!HF4+IO!HG4」と入力

する $($ 輸入」 $=\lceil($ 控除 $)$ 輸入」 $+\lceil$ (控除 $)$ 輸入 (直接購入 $) 」+\lceil$ (控除 $)$ 関税」 $+\lceil$ (控

除）輸入品商品税」)

手順 6. セル I4 に県内生産額を引用するため, 「=IO!HK4」と入力する

手順 7. セル D4 を選択し，「Ctrl」キーと「Shift」キーをおさえながら，「

（セル D4 から I4 が範囲選択される.）

手順 8.「Ctrl $+\mathrm{C} 」$ を押す（コピー）

手順 9.「Ctrl」キーと「Shift」キーをおさえながら，「】」キーを押す

（セル D4 から I193 までが範囲選択される.）

手順 10. $「 \mathrm{Ctrl}+\mathrm{V}\rfloor$ を押す（貼り付け）

作業 17. 最終需要部門名（文字）を引用し，確認しやすくする

セル D3 から I3 に部門名を記入する場合も，「引用する」方法を採る。

手順 1. セル D4 を選択し，「Ctrl」キーと「Shift」キーをおさえながら，「 （セル D4 から I4 が範囲選択される.）

手順 2.「Ctrl +C」を押す（コピー）

手順 3. セル D3 を選択し, 「Ctrl $+\mathrm{V} 」$ を押す（貼り付け）

これにより，図A9のようになる，図 A9の，四則演算を使っていないセル D3，E3，G3，I3 に は部門名が表示されるのに対し, 四則演算を使っているセル F3, H3 には值ではない文字があるた め計算できないことを示す，「\#VALUE!」が表示される。このように「=セル座標」だけ，つまり 四則演算などの計算を行なっていない場合は, 文字でもあっても「引用」される，この方法を使う ことにより，然るべき部門の值を「引用」できているかを，簡単に確認することができる. 


\section{A-7. 生産誘発額の計算}

\section{作業 18. 生産誘発額の計算（シート「F」）}

シート「B」にあるレオンチェフ逆行列と, シート「F」の D 列から I 列にある最終需要額の掛 け算を行う。

途中で, うまくいかなくなったら「Esc」キーを押し, 手順 1 からやり直すこと. (操作 7).

手順 1. シート「F」のセル K4 を選択する

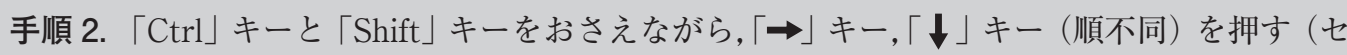
ル K4 から P193 まで範囲選択される.)

手順 3.「Shift」をおさえながら，つまり，「Ctrl」キーは離して，「ヶ」キーを押す （範囲選択からセル P1 から P193 が外れ，七ル K4 から O193 までになる.）

手順 4. 範囲選択されたセル K4 から 0193 を，同じ色に塗りつぶす（例えば，水色に塗る.）

手順 5. そのまま「=MMULT(B!D4:GK193,F!D4:H193)」と入力する

「そのまま」, つまりセル K4 を選択するなどの操作を何もせずに, 文字の入力をすること. 式の中で範囲選択の座標をマウスで指定するのに慣れていない場合は, 式を全て打ち込ん でしまうとよい，その際は，式を全角文字で書かないよう，また「!」の記入忘れ，「:」と「;」 や「」」と「.」を間違えないよう注意し，確認すること．

手順 6.メニュー上部にある「数式バー」を選択する（図 A8 の黒枠内）

この操作は, Excel のバージョンによって必要ないことがある.

手順 7.「Ctrl」キーと「Shift」キーをおさえながら，「Enter」キーを押す

\section{作業 19. 検算（シート「F」）}

シート「F」の $\mathrm{P}$ 列では，一致するはずの二つの值の差分を計算しているため，計算が正しけれ ば結果は全て「0」になる。

手順 1. シート「F」のセル P4 から P193 を同じ色で塗りつぶす（例えば，薄緑色に塗る。）

手順 2. セル P4 に,「=ABS(SUM(K4:O4)-14)」と入力する

手順 3.「Ctrl $+\mathrm{C} 」$ を押す（コピー）

手順 4.「Ctrl」キーと「Shift」キーをおさえながら，「】」キーを押す

(セル P4 から P193 まで選択される.)

手順 5.「Ctrl $+\mathrm{V} 」$ を押す（貼り付け）

手順 6. セル P1 に,「=SUM(P4:P193)」と入力する

なお,セル P4 から P193 を選択し, Excel 操作画面上の「ホーム」の「数值」欄で表示形式を「標 準」に設定すると, 小数点以下の值が表示される.これらの值は, 公表されたデータが端数を切り 捨てていること, Excel が割り切れない場合に計算を止めることによって生じる誤差である ${ }^{15)}$.

ちなみに,「ABS」は絶対值に変換する関数であるため,「差分」の内，負の值が正の值に変換 される。これにより「差分」を合計した時に，相殺されなくなる。 


\section{A-8. 生産誘発額の統合}

部門統合を手作業や Excel で行うことは，容易ではない。また，統合作業を間違いなく行えたか どうかの確認作業も大変である。そこで本稿では, VBA プログラムを作成し, 統合作業を行わせ るようにした，統合プログラム自体の説明は，他のプログラムと同じサイトで公表しているため省 略し，ここでは操作方法のみ説明する ${ }^{16)}$.

図 A10 は，統合プログラムを組み込んだ Excel ファイル「統合.xlsm」のシート「data」である.

図 A10 統合方法プログラム（統合.xIsm）の作業画面

\begin{tabular}{|c|c|c|c|c|c|c|c|c|c|c|}
\hline$\Delta$ & A & B & C & $\mathrm{D}$ & $E$ & $\mathrm{~F}$ & G & $\mathrm{H}$ & 1 & J \\
\hline 1 & & & & & & & & & & \\
\hline 2 & & & & & & & & & & \\
\hline 3 & & & & & & & & & & 0 \\
\hline 4 & 190 & & 37 & & & & & 37 & & \\
\hline 5 & 統合前 & 統合前部門名 & 統合後 & & 統合後 & 統合後部門名 & & 統合後 & 統合後部門名 & $\begin{array}{c}\text { 県内最終需 } \\
\text { 要計 }\end{array}$ \\
\hline 6 & & 嗀類 & 1 & & & 1. 農林水産業 & & & 1. 農林水産業 & 88,210 \\
\hline 1 & & いも・豆類 & 1 & & & 2. 鉱業 & & & 2. 鍍業 & 19,817 \\
\hline 8 & 3 & 野菜 & 1 & & & 3. 飲食料品 & & & 3. 飲食料品 & 203,617 \\
\hline 9 & 4 & 果実 & 1 & & & 4. 纖維製品 & & & 4. 擮維製品 & 41,819 \\
\hline 10 & 5 & その他の食用作物 & 1 & & & 5.パルプ・紙· 木製品 & & & 5.パルプ・紙・ 木製品 & 97,101 \\
\hline
\end{tabular}

統合に必要なデー夕は, 以下のように配置されている. 方法は作業 20 から作業 22 を参照.

・統合前の部門数（例：セル A4 に「190」と入力する）

・統合後の部門数（例：セルC4に「37」と入力する）

・統合前の部門番号（例：セル A6 から A195に, 自然数を 1 から順に入力する)

- 統合後の部門番号（例：セル C6 から C195 に, 統合後の部門番号 1 から 37 を適宜入力する)

・統合前のデータの入力（例：セル R6 から V195に, データを貼り付ける)

・統合後のデータの出力（例：セル J6 から N42 に, データが出力される）

•検算用の式（作業が正しく行われていれば，セル J3〜 N3 の值が「0」になる，作業 22 を参照）

作業 20. 部門名, 部門番号の入力（「統合.xlsm」のシート「data」）

プログラムに必要なデータを，統合プログラム「統合.xlsm」のシート「data」に用意する. 以降は, 操作方法の説明は省略し, 指示のみとする.

手順 1.これまで計算してきた Excel ファイル「山梨表 -2011-190.xlsx」のシート「IO」のセ ル C4 からC193を, 操作 4 を使って範囲選択し, コピーする

この場合は，セル C4 を選択，スクロールバーを使って C193に移動，「Shift」キーをおさ えながら，セル C193を選択する.

手順 2.「統合.xlsm」のシート「data」のセル B6 を選択し，「值」として貼り付ける（操作 6) 手順 3. そのままセル $\mathrm{Q} 6$ を選択し，同じく「值」として貼り付ける

手順 4. 37 部門表「23renkan-37bumon.xlsx」の部門名，手順 1 と同様に，シート「基本表」 のセル C4 から C40 を範囲選択し，コピーする

手順 5.「統合.xlsm」のシート「data」のセル F6 を選択し，「值」として貼り付ける（操作 6) 手順 6. そのままセル I6 を選択し，同じく「值」として貼り付ける

手順 7. セル A6, セル P6に 1 を入力, 以下, 195 行まで番号を振る $(1 \sim 190$ を連番で入力する. $)$ 手順 8. セル $\mathrm{E} 6$, セル $\mathrm{H} 6$ に 1 を入力, 42 行まで番号を振る（1～ 37 を連番で入力する. $)$ 
「統合.xlsm」のサンプルでは，手順 7 , 手順 8 の作業は不要である。なお，番号の振り方はいろ いろあるが, 今回は最大で 190 のため, 選択したセルの右下に現れる「フィルハンドル」（四角い点） を下に引っ張る方法でもよい.

\section{作業 2 1．統合する部門番号の入力（「統合.xlsm」のシート「data」）}

統合するためのデータを入力する．部門名は，山梨県企画県民部調查統計課（2016）の第 3 章第 4 節の「部門分類表」（p. 58～64）の統合小分類（190 部門）と統合大分類（37 部門）の部門番号 を比較しながら，分類に従って入力する.

山梨県表の場合, 190 部門表の並びは, 「20. その他の製造工業製品」以外は 37 部門の並びに沿っ ている。そのため，20 部門目に統合される部門に色を塗るなど，間違えにくくすることを勧める．

「統合.xlsm」を開いた時に，上部に黄色の带が現れ，「セキュリティの警告 マクロが無効にさ れました.」と出た場合は,「コンテンツの有効化」を押す ${ }^{17)}$.

手順 1.「統合.xlsm」のシート「data」のセル C6 から C195 に，統合後の部門番号を入力する 統合後の部門番号なので, 1 から 37 までの数值を入力することになる.

「統合.xlsm」にあるサンプルでは，入力は終わっているので，この作業は不要である.

手順 2.「山梨表 -2011-190.xlsx」のシート「F」で求めた生産誘発額（セル K4 から O193）を, 「統合.xlsm」のシート「data」のセル R6 に，「值」として貼り付ける（操作 6)

手順 3. セル A4 に統合前の部門総数「190」，七ル C4 に統合後の部門総数「37」を記入する

手順 4. Excel 操作画面上の「表示」を選択すると右側に現れる，「マクロ」を「選択」する

手順 5.「マクロ」の設定画面が現れ，「マクロ名」の欄に「統合」が表示されるので，選択する

手順 6.「実行」を押す

プログラム「統合」により 37 部門に統合された結果が，セル J6 から N42 に出力される.

\section{作業 22. 検算 (「統合.xlsm」のシート「data」)}

セル J3 から N3 には, 統合前の列の合計と, 統合後の列の合計の差分が表示されるようにして ある。これらの值が全てゼロになると，統合の計算で全ての值を使っていることになる．また 37 部門表の計算結果と 190 部門表の計算結果を 37 部門に統合したもので，一致するのは生産額のみ である。

この式により，プログラムが数值をシートに計算結果を一つ出力するたびに，全ての計算をし直 すため，時間がかかってしまうことがある。このセル J3 から N3 の式を消しておけば，統合の計 算は瞬時に行われるので，時間がかかる場合は式を消してしまい，以下の手順で計算式を入力し直 せばよい.

手順 1. シート「data」のセル J3 に，「=SUM(J6:J65)-SUM(R6:R205)」と入力する

手順 2. セル J3 の式を，セル J3 から N3 にコピーする

\section{作業 23．計算結果をX Ray のシートに貼り付ける}

作業 22 の作業で求めた計算結果，つまり統合プログラム「統合.xlsm」のシート「data」のセル I6 から N42 にある，37 部門に統合された生産誘発額を，バランスチャートを作成するプログラム を組み込んだ，ファイル「XRay-j.xlsm」に貼り付ける. 
「XRay-j.xlsm」では，移輸出と移輸入のデー夕をそれぞれ最大 5 項目に分け，示すことができる ようになっている，そのため，今回のように 2 項目しかない場合，データを離して配置する必要が ある、そのため, 今回はいったん全てのデータを移してから，移輸入のデータを移動する方法を説 明する。

手順 1. 操作方法5を使い,「統合.xlsm」のシート「data」のセル I6 から N42 範囲選択してコピー する

手順 2. 操作方法 6 を使い,「XRay-j.xlsm」のシート「data」のC11 に,「值」形式で貼り付ける (セル C11 から H42 に值が貼り付けられる.)

手順 3. セル G11 から H42 を範囲選択し，コピーする

手順 4. セル J11 に貼り付ける

(セル J11 から K42に值が貼り付けられる.)

手順 5. セル G11 から H42 を範囲選択し，「Delete」キーを押して消去する

今回は「切り取り」を使わず，「コピー」を使い，後から不要になった元のデータを消去する方 法を用いている．この方法を用いるのは，「切り取り」(Ctrl +X) をして「貼り付け」 $(\mathrm{Ctrl}+\mathrm{V})$ を用いれば，七ルの塗り潰しなどの，既にシートにされている設定を損ねるからである.

これでバランスチャートの作成に必要なデータは整った。後は,「XRay-j.xlsm」上で, バランス チャートを作成するためのプログラムを走らせるだけである。その方法，またバランスチャートの 仕組みや描画プログラムを組み込んだ Excel ファイル「XRay-j.xlsm」の使い方については, 宇多 (2019）をご覧いただきたい.

\section{〔注]}

6）本文で説明したように，Appendix で用いる産業連関表とプログラムの配布元には，本学会（PAPAIOS）の Web サイトの「IO 表」，「分析ツール」からたどることができる. http://www.gakkai.ne.jp/papaios/

7）「平成 23 年（2011 年）山梨県産業連関表の概要」https://www.pref.yamanashi.jp/toukei_2/HP/23renkan.html

8） Excel2003 までは, 横の上限が 256 列, 関数では 53 部門以上の逆行列は計算できないといった問題があった. しかし, 2007 以降はこれらの問題はなくなり, Excel だけでも多くの産業連関分析の計算ができるようになった.

9） Excelの操作方法を，より体系的に基本から学びたい方は宇多（2017）を，X Rayの改良のためプログラムそ のものの基礎を学びたい人は，宇多（2020）をご覧いただきたい. なお，今回，用いた環境はWindows10上の Excel2019であるため, 環境によってはできないことを説明しているかもしれないことを，ご了承いただきたい.

10）本稿の説明には出てこないが，間違えた時に「Ctrl +Z」（元に戻す）を押すことと，「Ctrl +S」(上書き保存) を押す習慣をつけること，の二つを強く勧める.

11) 本稿では, レオンチェフ逆行列 (I-A) $)^{-1}$ を B と表す.

12）生産額がマイナスの值を取ることもあるが, 今回は生産額が正の值の場合と同じ方法で対処する. 生産額がマイ ナスの值を取る理由は, 産業連関表の作成方法を細かく説明している宮沢 (2002), p. 77 ～ 81 を参照.

13）関数で空白のセルを引用した場合は, データなしと扱われる. 例えば, 平均点の計算では, 欠席者を計算から外 し, 平均点の計算に加えないように処理してくれる.

14）「BackSpace」キーを押した場合は，範囲選択された箇所に一箇所だけある，白いセルの文字だけが消去される.

15）セル P1 の值は, 筆者の環境では「0.317」程度であった. 環境によって異なる場合があるが, 数值の四捨五入な どによる省略や Excel の計算精度を考えれば，誤差の絶対值の合計はその前後程度に収まるはずである。

16）VBA を使えるようにするには, 設定変更が必要な場合がある. 方法は, 宇多 (2019), 宇多 (2020) を参照.

17）所属する会社や組織のセキュリティーの都合等で, Excel VBA を動かない場合の対処は適宜, お願いしたい. 